\title{
Mexico's Campaigns and the Benchmark Elections of 2000 and 2006
}

\section{Citation}

Domínguez, Jorge I. 2012. Mexico's Campaigns and the Benchmark Elections of 2000 and 2006. In The Oxford Handbook of Mexican Politics, ed. Roderic Ai Camp, 523-544. Oxford: Oxford University Press.

\section{Published Version}

10.1093/oxfordhb/9780195377385.013.0022

\section{Permanent link}

http://nrs.harvard.edu/urn-3:HUL.InstRepos:11870356

\section{Terms of Use}

This article was downloaded from Harvard University's DASH repository, and is made available under the terms and conditions applicable to Other Posted Material, as set forth at http:// nrs.harvard.edu/urn-3:HUL.InstRepos:dash.current.terms-of-use\#LAA

\section{Share Your Story}

The Harvard community has made this article openly available.

Please share how this access benefits you. Submit a story.

\section{Accessibility}




\section{Chapter 22}

\section{Mexico's Campaigns and the Benchmark Elections of 2000 and 2006}

\section{Jorge I. Domínguez}

It was 11 PM on July 2, 2000. The television networks, broadcasting from the Federal Electoral Institute (IFE), turned their cameras on José Woldenberg, the Institute's president, who was about to give the preliminary results of the voting in Mexico's 2000 presidential election. Speaking in a rushed monotone, Woldenberg reported on the "quick counts" and other technical means of verifying the voting in advance of the complete count. He referred to statistical significance or the lack thereof of these various tests, making the dramatic appear dull; he concluded on the cautious note that Vicente Fox, the candidate of an opposition party, Partido Acción Nacional (PAN), seemed ahead.

With a break that lasted only seconds, the television networks turned their cameras on President Ernesto Zedillo at his presidential office in Los Pinos. Zedillo, dressed formally for this occasion, was wearing the tricolor presidential sash across his chest. Behind him were two icons of republican Mexico. One was a gigantic flag of Mexico. The other was a portrait of the nineteenth-century president Benito Juárez. Zedillo spoke deliberately, pausing for effect and clear public understanding. He noted that the audience had just heard the preliminary results from the IFE president. Without hesitation, he boldly congratulated Vicente Fox on his election as president of Mexico and pledged that his administration would cooperate fully during the upcoming five-month transition 
period. He called upon his party, the Partido Revolucionario Institucional (PRI), to be proud of a long record of accomplishment in the transformation of Mexico and, in that spirit, to support the election outcome.

Again with a short break lasting only seconds, the television cameras next turned their lights on the PRI headquarters, specifically on the party's presidential candidate, Francisco Labastida. All PRI leaders looked stunned. Some in the crowd shed tears. Then someone was sufficiently inspired to start singing the national anthem, and others joined in. The special transmission in its three parts lasted about ten minutes. It would be followed with images of Fox supporters celebrating in downtown Mexico and elsewhere as the evening wore on.

This brief televised news special powerfully portrayed and synthesized six key processes that had changed Mexico's political regime, culminating in the 2000 national election campaign. First, the results were sanctified on national television. Mexico's largest and most powerful television network, Televisa, had long been a close ally of the PRI presidents (Lawson 2002). In the 1988 presidential election, for example, Televisa showed images of the leading opposition presidential candidate, Cuauhtémoc Cárdenas, but it rarely broadcast his voice, relying instead on its own news commentators to put a spin on Cárdenas's remarks. In the 2000 presidential election, Televisa became somewhat more independent of the PRI; its coverage of the election was more balanced than in the past. Yet during the 2000 presidential election viewers who relied for their news coverage on Televisión Azteca, Televisa's principal competitor, were significantly more likely to vote for Vicente Fox (Lawson 2004b). On election night, however, all television stations conveyed the same message: Fox had won. 
Second, the IFE president was the first to speak during the tripartite broadcast on election night. In response to the contested legitimacy of the 1988 presidential election, Mexico's opposition parties negotiated with the PRI presidents, Carlos Salinas and Ernesto Zedillo, a series of institutional reforms to ensure that elections would be conducted fairly and fraud-free. Among the most significant changes would be the creation of the IFE to prepare, conduct, and oversee the national elections and the establishment of electoral courts to address specific election disputes (Eisenstadt 2004). Similar institutions were established at the state level. The IFE debuted during the 1997 nationwide congressional elections, when the PRI lost control of the Chamber of Deputies for the first time since its predecessor political party was founded in 1929. In previous presidential elections, the PRI had controlled the electoral processes; the opposition believed that these electoral institutions were not impartial entities and could not conduct and ensure fair elections. The IFE embodied the political agreement that made a democratic transition possible by means of the 2000 presidential election. It was indispensable that the IFE president should lead the election night broadcast.

Third, the IFE president spoke about statistics, technical procedures, multiple tests, and other arcane instruments to ensure fairness and impartiality, which had never before been how Mexicans heard about their election. For the 1988 presidential election, for example, the Ministry of Government (Secretaría de Gobernación) prohibited the Gallup Poll to conduct an exit poll on election day. ${ }^{2}$ The minister of government, Manuel Bartlett, not an independent entity like the IFE, was the election's chief overseer; on election night, Bartlett's officials announced that the computer system had broken down and there would be no preliminary results, but surely the PRI had won; the president of 
the United States congratulated Salinas on his election. In contrast, in 2000 the only source of legitimate authority was the voter, not the government minister or the U.S. president, and the only way to provide information regarding credible-enough preliminary election results was to rely upon statistical procedures. Public opinion polling before the election and on election day had become an instrument to inform Mexicans and to provide them an independent means to monitor the election itself. Pollsters became agents of Mexico's democratization (see also Parás and Basáñez in this volume).

Fourth, President Ernesto Zedillo was one of the architects of Mexico's democratic transition. He understood the importance of deploying fully the majesty of the presidential office on the historic occasion of his election announcement. Mexicans have been deferential to their presidents even when citizens in other countries may have been more critical of their chief executive. For example, Mexico suffered a severe and prolonged economic recession during the entire six-year term of President Miguel de la Madrid. Yet in May 1988, just weeks before the national election, five out of every eight Mexicans held a favorable opinion of President de la Madrid, rating him at least 7 on a 10-point approval scale (Domínguez and McCann 1996, 101). Zedillo inherited some of that presidential aura, but he had to earn his popularity. Mexicans did not fully blame him for the 1994-95 severe economic plunge, believing that he had inherited rather than created the crisis, but Zedillo's popularity fell close to a rating of 5 on the 10-point approval scale in early 1995. By March 2000, however, his popularity exceeded 7 on the 10-point scale (Lawson 2004a, 4). He had won the confidence of Mexicans. They looked to him to interpret the IFE president's statistical mumbo jumbo and to communicate clearly that he would oversee an orderly, peaceful, and fair transfer of the presidency to 
the opposition, based on a free election under universal suffrage, for the first time in Mexican history.

Fifth, the PRI itself had changed. As well put in the title of an article by Silvia Gómez Tagle (1989), one of the PRI's problems was that it found it difficult to lose. It too was a key player in this democratic transition, notwithstanding its authoritarian past and some continuing instances of state-level or municipal PRI resistance to accept the national outcome. Following the 1988 national election, the PRI still claimed the presidency, a majority in both chambers in Congress, and all state governorships. This oversized political coalition encompassed street toughs and cosmopolitan financiers, government technocrats and savvy politicians, hard-fisted enforcers and would-be liberalizers. The protracted Mexican democratic transition from the late 1980s to the 2000 presidential election coincided with a major transformation of the framework for the Mexican economy, moving away from an import-substitution industrialization and natural resource-dependent model to a much more market-conforming, internationally open manufacturing economy. The simultaneity of these processes of political and economic regime changes stimulated numerous disputes within the ruling party, generating complex and shifting alliances over time as well as across issues and the national territory (Haber et al. 2008).

As a result, the PRI itself became more internally pluralistic, more difficult to control, and more aware of the utility of coalition making, alliances, and conciliation for the advancement of its own goals. PRI presidents had in the past imposed their own chosen candidate upon the party. In advance of the 2000 presidential election, Zedillo could not impose his preferred candidate (Francisco Labastida); the PRI held its first-ever 
presidential primary, in which Labastida defeated Roberto Madrazo. Many in the PRI, certainly Zedillo, and probably Labastida were ready to play by democratic rules in 2000 . In leading the PRI to consent to the choice of voters, they helped to enact Mexico's democratic transition - at the expense of their own power.

Sixth, the PAN had changed too. Perennially accustomed to losing, playing the martyr role in fraudulent elections, and complaining about unfairness, the PAN led by Vicente Fox entered the 2000 presidential campaign determined to win. In previous elections, PAN leaders had warned Mexican citizens about the likelihood of electoral fraud. This discouraged the better informed among likely PAN voters from going to the voting booths on election day: Why bother to vote if PAN leaders themselves devalued the utility of the election (McCann and Domínguez 1998)? In preparation for the 2000 presidential election, Fox and other PAN leaders changed their message: Make sure to vote and in so doing be vigilant to prevent election fraud. The party of martyrs had become the party of winners (Mizrahi 2003).

The 2000 Mexican national election was, of course, about much more than these six considerations. It was the result of a complex process whereby Mexican voters became, for the first time in the country's history, the principal protagonists of the construction of a more democratic political regime.

I next explain the institutional reforms that made fraud-free elections possible in Mexico and the impact of those reforms on the major political parties. These changes made it possible for the PAN to win two consecutive presidential elections and turned the Partido de la Revolución Democrática (PRD) into a highly credible contender that nevertheless found it difficult to win first-past-the-post elections (president, governor); 
the change enabled the PRI to continue to win many subnational elections (governor, mayor, federal deputy and senator), but it also rendered it more vulnerable to defeat in presidential elections. I then examine how Mexican voters think about the elections and argue that campaigns have a significant impact on shaping the preferences of voters: in both the 2000 and the 2006 presidential election, the early front-runner lost the election. (For the results of the 2000 and 2006 elections for president and federal deputy, see Table 22-1.)

$<$ COMP: INSERT TABLE 22-1 NEAR HERE $>$

\section{Institutional Change: Preparing for Democratic}

\section{Elections}

Mexico's electoral institutions and procedures had to change to make possible the much freer and fairer national elections for Congress in 1997 and for the presidency and Congress in 2000. Myriad changes were enacted following the 1988, 1991, and 1994 national elections. The 1996 electoral reform turned out to be decisive. Two changes in particular (there were many more) mattered most, namely, the independence of the Federal Electoral Institute and campaign financing rules.

First, the long list of Mexico's reforms of its electoral laws changed the IFE's membership, rules, and powers. The IFE was created in the 1989-90 reform, but it remained dependent on the minister of government. In the 1996 reform, the minister was removed as the IFE's head, and political party representatives and members of Congress lost their votes on the IFE, retaining only their right to speak at IFE meetings. Only nine 
citizen councilors retained both voice and vote in the IFE's General Council. Each councilor is elected by the Chamber of Deputies by a vote of two-thirds of its members, which ensures that councilors could not be chosen by a single political party. The term of a councilor is nine years, to outlast any public official whose election they oversaw; no Mexican elected official has a term longer than six years. IFE councilors elect the president of their General Council, who is also the IFE's chief executive (Gómez Tagle 2004).

Second, the Mexican government's various agencies and state enterprises had long been the informal sources of financing for the PRI, in addition to private contributions. The 1993 electoral reform included the first restrictions on private and governmental financing as well as the first reporting requirements. The 1996 reforms leveled the playing field. There would be significant public funding for Mexican elections. As Kenneth Greene (2007, 108-13) has documented, for the 1997 national congressional election — the first one under the new regulations — public financing was twelve times its 1994 nominal peso value, or 4.4 times larger as a proportion of gross domestic product, which made Mexican elections, then and in subsequent elections, among the most expensive per capita in the world. The law reduced private financing to a negligible sum, and more important, detailed reporting requirements were put in place; the IFE was given powerful investigative and punitive powers, which it has exercised systematically since then, imposing stiff fines on parties that break the rules. Nevertheless, after the 2000 election it became clear that the instruments at the IFE's disposal were still insufficient to keep track of irregularities and avoid significant illegal funding (Peschard 2006). For the 1997 election, the combined opposition parties did have more funds and more television 
air time than the PRI. Such a change in public financing would have a powerful effect on Mexican politics, but it would also render Mexican elections extremely expensive, fueling not just fairer electoral competition but also harsh negative campaigning (Aziz

\section{Nassif and Isunza Vera 2007).}

The puzzle is why the powerful PRI agreed to rules that increased the odds that it would lose its power. There are three reasons: rulers sought to increase the likelihood of governability; rulers sought to increase the likelihood of acceptance of prospective election outcomes before the elections; and the process of change was drawn out over several years and Mexico was hit by a massive economic crisis in 1994-95, which made strategic calculation more difficult and mistakes more likely.

The process of significant electoral reform began in the aftermath of the sharply contested 1988 presidential election, when the opposition, and many others inside and outside Mexico, questioned the legitimacy of Carlos Salinas's election. Salinas agreed to electoral reforms to increase his chances of governing Mexico effectively. In the past, the prospects of governability might have improved through more effective social and economic inward-oriented development policies. Salinas successfully tried both. But the opposition had grown much more than in the past. The economic crisis of the 1980s had also made inward-oriented development policies look much less promising. To make Mexico's economy grow, Salinas looked to the United States; his own memoirs (Salinas 2000) open with two hundred pages on his policies to renegotiate Mexico's international debt and sign the North American Free Trade Agreement (NAFTA). And to get NAFTA ratified in the U.S. Congress (Domínguez and Fernández de Castro 2009, 105-11) the niceties of elections in Mexico had to be addressed; just committing massive election 
fraud would not do. Therefore the Salinas reforms sought to obtain the PAN's consent, in which case he did not have to make concessions to the political Left that was reconstituting itself as the PRD. Yet another round of reforms was put in place in anticipation of the 1994 presidential election. The PRI wanted to secure the PAN's support for the electoral process in advance of the election. Moreover the success of the Salinas government in securing public support convinced the PRI leaders that they could win a free and fair election in 1994, in which case making these institutional concessions seemed safe (Magaloni 2006, chapter 8). PRI leaders had no way of foreseeing—just as financial analysts, Mexican and U.S. government officials, and international financial institutions for the most part did not - the severe financial and economic crisis that shocked Mexico in late 1994 and in 1995, with disastrous consequences for PRI political support.

President Zedillo's motivation for the 1996 electoral reform was analytically similar to President Salinas's, even though the context differed. Both presidents worried about their prospects for governability at home and in their relations with the United States. The 1996 electoral reform was Zedillo's attempt to get both the PAN and, for the first time, the PRD to consent to the institutions that still harbored PRI power. Zedillo was also motivated by a search for consent to the 1997 election before it was actually held. And he has an additional reason for these changes: he had distanced himself from PRI's traditional bosses and actually needed greater toleration and at times support from the opposition parties in Congress (Eisenstadt 2004, 35-38). Yet there may have been a miscalculation, an underestimate that the reduction in the size of the public sector, the leaner federal bureaucracy, and the privatization of state enterprises, along with the new 
rules in campaign financing, would at long last deprive the PRI of what Greene (2007, 39). called its "hyper-incumbency advantages."

The IFE's independence and professionalism and the lavish public financing of the campaigns of the various political parties, including those in the opposition, would be keys to the 2000 and subsequent campaigns and elections. Having witnessed the PRI's loss of its majority in the Chamber of Deputies following the 1997 election, opposition politicians at long last contemplated the prospects of winning. Institutional change made campaigning and winning thinkable in a democratic context.

There were, to be sure, many important changes as well in Mexico's civil society, which contributed to the opening up of the political system. One symbolic watershed moment occurred in 1985, when neighborhood associations in Mexico City responded to a damaging earthquake and did so in the face of governmental ineptitude and independent from the PRI. Some of these social movements would feed into the PRD. At the same time, the Roman Catholic bishops began to urge the faithful to participate in politics and became more likely to comment on the social teachings of the Catholic Church (Camp 2008). This may have increased electoral participation by Roman Catholics and may have indirectly favored the PAN.

Mexico did not change all of its rules for elections. Institutional continuity also shaped the process of political change. The Mexican Constitution of 1917 features a federal structure. Democratization gave new meaning to the jobs of governors and mayors, creating the necessity of vigorous campaigning in the face of new contestation in states and municipalities. From the 1960s to the 1990s, laws for nationwide legislative elections changed consistently away from exclusive reliance on single-member plurality- 
district (SMPD) methods for aggregating votes. The Chamber of Deputies has five hundred members, of whom three hundred are elected through SMPD, but the other two hundred are chosen proportionate to the votes cast for party lists—-resembling the method first invented in the founding constitution of the German Federal Republic. In the 1990s the rules to elect the 128 federal senators changed as well: two are elected through SMPD where each state is the district, one is chosen with the state as district but from the second most-voted party, and 32 are elected proportional to the nationwide vote for party lists. All posts, from president to mayor, are strictly term-limited and have been so for decades (Camp 2007, 183-84).

The results of the institutional continuity, and the shift toward proportional representation, have three consequences. First, every year there are some municipal, state, congressional, or presidential elections; in July 2010, for example, Mexico elected twelve state governors but no president or members of Congress. Second, the no-reelection rule requires politicians to rely on their political party for a career trajectory; a politician cannot serve in the Senate for three decades, relying on personal political resources, but instead must use the party to look for his or her next post. Third, the introduction of elements of proportional representation made it possible for three big political parties to have strong representation in Congress while strengthening partisanship, because the parties compose the lists from which legislators are elected.

\section{The PRI: From the Party of the State to the Party of}

\section{the States}


On the eve of the start of its transformation, the PRI, the party of the state, was also known as the party without real members (Garrido 1987). As the 1990s and especially the 2000s unfolded, a new PRI, with real supporters and anchored in the states of the Mexican federation, emerged and became consolidated. In so changing, the PRI stands at midpoint on a spectrum of comparative parties that ranges from Brazil's Democratic Movement Party, which wins state governorships but not the presidency and, Argentina's Justicialistas (Peronists), who win most governorships but also the presidency often enough. The new PRI has consistently won the majority of governorships, but it has not won the presidency since the 1994 elections; on July 4, 2010, it won nine of the twelve governorships at stake.

The PRI's transformation took place from 1988 to 2000. As Díaz-Cayeros $(2006,98)$ has argued, all major political players in the old authoritarian PRI system had played by the rules of a game of progressive ambition whereby the national PRI structured the career trajectories of its leading politicians, relying on federal control of staggered state elections and the no-reelection rule. The shift began under Salinas and was built on an analytical triad. First, the president had once behaved as the principal of this complex organization and the state governors were his agents; PRI candidates for governors before 1988 required presidential clearance, and the president could and did dismiss governors over time. Second, responding to the incentives of governability noted above, the president greatly increased the uncertainty of the governors that they could count on his support. Third, the agents stopped responding to the presidential principal and became principals of their own territorial organizations. Once the PRI lost the presidency, the party's federalization deepened. 
President Salinas most sharply displayed the powers of the presidency, removing thirteen governors from office (four other governors resigned to accept a federal appointment) during his six-year term — the largest number of gubernatorial removals since the proto-party's birth in 1929 (Mexico has thirty-two units in the federation; Eisenstadt 2004, 96, 104). Then in 1989, Salinas recognized the PAN's victory in the gubernatorial election for Baja California Norte. Yet it was another Salinas policy, which came to be known as concertacesiones, that most alarmed PRI politicians. After a gubernatorial election, the opposition would cry fraud, and in several cases Salinas turned the governorship over to the leading opposition party in those elections, though not necessarily to the opposition candidate who had won the most votes. In 1991, for example, the PRI claimed the most votes in the gubernatorial election in the state of Guanajuato, but after protests, Salinas awarded the governorship to the PAN, albeit not to the PAN's candidate, Vicente Fox, who thus began his rise as a magnet for anti-PRI opposition en route to his election as president in 2000. The message to PRI politicians was clear, however: they could not count on the president to get them into office.

In 1994 the newly elected Ernesto Zedillo tried a similar concertacesión in the state of Tabasco. The Tabasco PRI had violated campaign spending limitations fiftyfold and with impunity on behalf of its candidate, Roberto Madrazo. The principal opposition candidate, Andrés Manuel López Obrador, cried foul. The forced resignation of Governor-elect Madrazo was negotiated, but then the Tabasco PRI revolted. Zedillo backed down. Madrazo became Tabasco's governor but owed Zedillo no loyalty. At the end of the 1990s, Governor Madrazo challenged President Zedillo's choice for the PRI presidential nomination, Government Minister Francisco Labastida; the PRI held its first- 
ever party primary, which Labastida won. An angry López Obrador moved to Mexico City, became its mayor in 2000, and ran as the PRD candidate for president in 2006 (Eisenstadt 2004, 96-113).

President Zedillo could no longer protect the PRI governors from electoral defeat, but neither could he hurt them. Democratic Mexico rediscovered the federal structure of the 1917 Constitution, which recognizes considerable authority and powers in the state governors. Governors built their own political bases of support and fostered their own political agendas. They had a much greater incentive to focus on electing candidates in their own states than to help elect their party's presidential candidate.

The loss of the presidency in the 2000 election accelerated the PRI's transformation from the party of the state into the party of the states. PRI governors were free from the political control that PRI presidents had long exercised over them (Modoux 2006; see also Beer's chapter in this volume). The PRI still uninterruptedly wins more governorships than the next two biggest parties combined, the PRI and the PAN, even as it lost the presidential election again in 2006. The PRI has retained many governorships that it has always held, and it has also won back the governorship in states where it once lost, including symbolically (PAN-leaning) or materially important states such as Chihuahua and Nuevo León. The PRI has demonstrated time and again that it can elicit the support of many voters, now as the party of the states.

\section{The PAN: From Martyrdom to Power}

The title of this section is borrowed from Mizrahi's (2003) book because it captures well the PAN's transformation. Mizrahi's work and Loaeza's $(1999,2003)$ magisterial 
historical study of the PAN account for a clear process of change. The PAN was born in 1939 as a party of resistance to the revolutionary anticlericalist policies of Plutarco Calles and Lázaro Cárdenas. Roman Catholicism mattered deeply to the PAN's ideas, leaders, and members. It behaved largely as a protest party through the 1970s. The PAN was reborn in the 1980s, thanks to the influx of entrepreneurs and a more politically active Roman Catholic laity. These neopanistas shaped the PAN as a territorial party, strong principally in central and northern Mexico. The PAN has struggled between its Christian Democratic heart and its neoliberal political and political-economy ambitions. Its internal rules were designed to prevent penetration by the state or the PRI, and thus it is difficult to join the party. The PAN deliberately restricted membership to a select number of people who subscribe to its platform, fashioning strict rules for party affiliation akin to joining a club, including the obligation to attend party school during a probationary period.

The PAN prepared to win the 2000 presidential election because it believed that the change in the electoral institution, the generous public financing of campaigns, and the results of the 1997 congressional elections made a presidential election victory possible. This required breaking with past purity, not just by welcoming ever more supporters who had not learned the party's political catechism, but also by forming two sorts of alliances. The PAN entered the 2000 presidential election in alliance with Mexico's Green Party (PVEM), which was more an opportunistic and clientelist party than an environmentalist party. The PAN's Alliance for Change also welcomed an entity, the Amigos de Fox, created just for this election campaign as an instrument to obtain support from political independents and partisans of other parties. Among these new friends were prominent 
intellectuals who had hitherto been aligned with the political Left—quite a shift for a PAN long anchored in the center Right on both economics and Catholicism—such as Jorge Castañeda and Adolfo Aguilar Zinser, who would become President Fox's foreign minister and UN ambassador, respectively. This deliberate thrust for power resulted from PAN candidate Vicente Fox's choices: he wanted to win and concluded that partisan votes would not suffice for this purpose. Fox's instinct would prove correct. In 2000 the PAN and its allies were barely ahead of the PRI in the elections for deputies and senators but comfortably ahead of the PRI in the presidential election.

\section{The PRD: Between Movement and Party}

The political Left emerged from the 1988 presidential election to organize and reorganize its forces into a new party, the PRD, which drew strength from three different sources. Many were attracted to the first political vehicle on the Mexican Left that seemed capable of winning political power to enact significant change. Others came from the myriad small parties with modest voter support long extant on the Mexican Left, ranging from the old, renamed Communist Party to parties that had at times been PRI coalition partners for specific elections. The third source was political defectors from the PRI led by a former PRI governor of the state of Michoacán, Cuauhtémoc Cárdenas, and a former PRI party president, Porfirio Muñoz Ledo. Cárdenas lent visibility and dignity to the new party; Muñoz Ledo was its lead strategist. PRI defectors would continue to nourish the PRD with candidates over the next two decades.

These sources of strength also posed four distinct challenges. First, many on the Left believed that they constituted the majority of Mexicans. The long rule of the PRI had 
tainted elections. For the movement-oriented PRD supporters, filling the public square, the Zócalo, and the streets was a clearer demonstration of majoritarian power than votes on election day. Theirs was a movement certain of its correctness rather than a party ready for elections and bargaining. This ideology added zeal and commitment to the party but not electoral readiness, and, as would become evident after the 2006 election, it would reduce the willingness of many of its members to accept the verdict of voters on election day. Second, the collage of little parties led to a collage of little factions. The Mexican Left had been fragmented for various reasons, but one of them was a fierce adherence to principle and a concomitant unwillingness to compromise. The old parties were not identical to the new factions, but the spirit of intransigence did carry from the old Left to the new party. Third, the PRD's sustained strategy to continue to lure defectors from the PRI throughout the 1990s and into the 2000s lent it an air of opportunism that turned off voters and made internal organization, including internal democracy, more difficult (Bruhn 1997; Prud'homme 2003). Fourth, Cárdenas was not just a politician but also a secular saint for this party. He revived the Left in time for the 1988 election and brought it close to national victory. In the 1997 election, he would become the first PRD mayor of Mexico City and the presumptive next president of Mexico as a result, even though he had performed poorly during the 1994 presidential election campaign. The personalist strains in the PRD then reemerged around the candidacy of Andrés Manuel López Obrador. Neither the PRI nor the PAN was as bound to the political fortunes of a single, fallible human being as the PRD was. 


\section{Citizens Respond to Institutional Democratization:}

\section{Parties, Incumbents, the Economy, and the Candidates in 2000 and 2006}

In the 2000 and 2006 presidential elections, as well as in each election since 1988, three variables explained much about the distribution of voter preferences: partisanship, assessment of the incumbent president's performance, and assessment of the country's economic circumstances (for prior elections, see Magaloni 1999; Domínguez and McCann 1996). Each was consistently significant in statistical and other analyses of public opinion and electoral behavior (Domínguez and Lawson 2004; Domínguez et al. 2009). Beginning in 2000 and continuing in 2006, candidate assessments also played a significant role; campaign effects, as the next section shows, mattered in both elections.

The role of partisanship is noteworthy because Mexico's political parties are relatively recent creations. The PRD was born out of the sequel to the 1988 presidential election. The PAN greatly expanded its support base and fine-tuned its political message during the 1980s. And the PRI transformed itself from being the figurative "Ministry for Elections" to becoming a political party with real members and a wide network of supporters across all of the country's regions. As Alejandro Moreno $(2009 \mathrm{~b}, 49)$ has put it, "From 1996 to 2007, no fewer than two-thirds of Mexicans have considered themselves PANistas, PRIistas, and PRDistas." Partisanship in Mexico has also been very stable (Moreno 2003, 80; 2009b, 132); during the respective political regime transitions, partisan volatility was lower in Mexico than in Greece, Portugal, or Spain (Ortega and Somuano 2003, 33-34). Partisanship became akin to the faith of new 
converts: strong and loyal. For the 2006 election, for example, half of the electorate had decided for whom it would vote for president before the presidential campaign began and any candidates had been chosen; each individual gave a consistent response to three waves of public opinion interviewing of the same respondents (Flores-Macías 2009). Such a stand-pat voter would characteristically vote for the same party independent of the identity of its candidates.

The assessment of an incumbent president's performance varies during an election campaign, but in both the 2000 and the 2006 presidential elections the opinion of the incumbent president, largely fashioned in advance of the campaign, was not itself much affected by the campaign. Presidents Zedillo and Fox were both very popular by the end of their respective presidencies. In both elections, the assessment of the president's performance was a significant factor in shaping the voting choice (Moreno 2009b, 279). The assessment of the president's performance has the greatest impact on voting preferences when voters lack much information about the candidates or the issues; the impact of this assessment therefore attenuates during the course of the presidential campaign as voters gain such information (Romero 2009).

Opinions about the economy come in four flavors: What is your view of the past and the future? What is your assessment of your own or your country's economic circumstances? In both the 2000 and the 2006 presidential elections, attitudes toward personal economic circumstances mattered less than attitudes regarding the national economic situation (known as sociotropic voting). In both elections, retrospective and prospective economic assessments shaped voter preferences, but in both elections prospective economic voting mattered more (Magaloni and Poiré 2004b; Moreno 2009a). 
Prospective economic assessments are, of course, much more vulnerable to manipulation during the campaign, and their weight in shaping the voting choice is therefore crucial.

A key change from the elections between 1988 and 1997, but a common theme for the elections of 2000 and 2006, was the decisive importance of the presidential candidates. Vicente Fox had only joined the PAN in 1987; he was a neopanista recruit who built his own political organization both inside and outside the PAN. By the time the PAN was ready to choose its presidential candidate for the 2000 election, no one else contested the nomination. Cuauhtémoc Cárdenas and the PRD were like conjoined twins; it seemed inconceivable that anyone other than Cárdenas would lead the party in the 2000 election, just as he had led it for the 1994 and 1988 elections. The only question prior to the PRD's renomination of Cárdenas was whether the PRD would support Fox, the PAN presidential candidate, as part of an agreement to ensure significant PRD representation in Congress; no such agreement was reached. As noted earlier, for the first time in its history the PRI chose its candidate in a primary election instead of relying on the longstanding practice of dedazo, in which the incumbent PRI president chose his own successor; Francisco Labastida became the nominee upon defeating Roberto Madrazo (Bruhn 2004).

In anticipation of the 2006 election, only the PRD had a candidate whose nomination was akin to a coronation, fully in the expectation that he would go on to win the presidency, Andrés Manuel López Obrador (Trelles and Zagal 2004), who, like Cárdenas for the 2000 election, was the PRD mayor of Mexico City. The PRI and the PAN witnessed internal party contestation. Former energy minister Felipe Calderón went on to defeat President Fox's preferred candidate, former minister of government Santiago 
Creel, in a primary election that also included a third candidate, former Jalisco governor Alberto Cárdenas. Calderón's victory, unexpected by many at the time, rested on two factors. First, only PAN members and affiliates could vote in the primary, and the PAN had strict rules for both categories. Second, Calderón's career had been spent in PAN party organization, serving as both PAN secretary-general and president. When the PRI held its second presidential primary, Roberto Madrazo (Trelles and Zagal 2006), defeated for the PRI's 2000 presidential nomination, had become PRI party president and the organizer of the PRI's successful comeback in the 2003 congressional election and in many gubernatorial elections during the first half of the decade. Madrazo won the PRI presidential primary in 2005; his main opponent, state of Mexico governor Arturo Montiel, was the object of accusations of corruption that forced him to withdraw his candidacy in the middle of primary elections. One effect of winning in this way was to remind voters of Madrazo's reputation for heavy-handedness and thus weaken him as a general election candidate (Shirk 2009; Bruhn 2009; Langston 2009; McCann 2004; Hernández Rodríguez 2009).

Statistical and qualitative assessments of both the 2000 and the 2006 presidential elections show that the assessments of candidate traits matter. In both elections, assessments of candidate and party identification interacted in important ways (Guardado Rodríguez 2009). Television debates have relatively little impact in countries that are accustomed to having many of them, but they have been sufficiently rare in Mexico that they are one factor in shaping the election choice. Negative advertising also took off as a campaign tactic in the 2000 election (Virriel López 2000) and resurfaced vigorously in the 2006 election. In both elections, negative advertising significantly helped the eventual 
winner of each election, Fox and Calderón, respectively. In the 2000 election, Labastida's effort at negative advertising backfired on him. In the 2006 election, the PRD's López Obrador responded belatedly to the negative advertising aimed at him—portraying him, inaccurately, as a radical clone of Venezuela's president Hugo Chávez — and his response would turn out to be also ineffective in the end (Lawson 2004b, 2004c; Moreno 2004, 2009a, 2009b, 203-40; Magaloni and Poiré 2004b; Greene 2009). In the 2006 election, there was more negative advertising in the legislative than in the presidential election; ironically the PRD candidates for federal senator and deputy relied much more on negative advertising than candidates of other parties, so much so that it backfired on them (Freidenberg and González Tule 2009), as it had on Labastida in 2000. The disjunction in the use of PRD negative advertising in the 2006 presidential (limited use) and legislative (extensive use) elections highlights the PRD's difficulty fashioning a unified party campaign in that election.

Mexicans are not extraterrestrials. The importance of economic voting and the interaction between partisan and candidate assessments in Mexico, on the one hand, and economic assessments, on the other, makes Mexican voters akin to those in the major North Atlantic democracies, where economic and partisan voting have long been important factors (Lewis-Beck 1988; Alesina and Rosenthal 1995). Partisanship is a relatively new feature in the Mexican electorate, but it has now sunk deep roots in the electorate and has endured since 1988; such stability in partisanship despite many changes is akin to stability in partisanship in the United States, notwithstanding many other changes. In part because partisanship in Mexico is relatively recent, the proportion of what might be described as "core" partisans is not large, though as already shown the 
proportion of voters who consistently vote for the same party is very substantial. Core partisanship has also weakened over time in the North Atlantic democracies, thus rendering levels of partisanship comparable between them and Mexico (Campbell et al. 1960; Nie et al. 1976; Shickler and Green 1997). Similarly the impact of the mass media, including negative campaign advertising, on presidential elections also makes Mexico and its voters part of the ensemble of democratic polities (Norris et al. 1999; Lau et al. 1999; Zaller 2002).

In short, Mexico had never had a democratic political system. The process of democratization that began in the 1980s, picked up speed in the 1988 election, and reached a key turning point in the 2000 election transformed Mexican citizens into voters, shaped and motivated by factors that are common across constitutional democracies, many of which were established a century or more before Mexico's.

\section{Did the Campaign Matter for the Election Outcome?}

At the start of the 2000 and 2006 campaigns, the PAN presidential candidate was not in first place. In each election, the PAN's victory had to be constructed, and therefore each campaign had a decisive impact. In 2000 the PRI's Labastida had been ahead in the early stages of the campaign but went on to lose to Fox. In 2006 the PRD's López Obrador was similarly in front in the early part of the campaign but, in the end, was defeated by the PAN's Calderón.

One key role of national campaigns — not just Mexico's—is to move public opinion toward the expected outcome. As events unfold, voters update their information (Holbrook 1996). Some voters change their views during a campaign, but most do not, 
yet the fact that the views of most do not change does not mean that the campaign has no effect. Rather, the campaign conveys information to voters that enables them to behave according to what may be called the underlying variables, among them their partisanship and economic assessments, provided the parties and the candidates conduct an effective campaign (Gelman and King 1993). Voters move toward the expected outcome during a well-run campaign.

The 2000 election, however, moved Mexicans toward the unexpected outcome. At the start of the campaign, voters had a very high opinion of the incumbent PRI president Ernesto Zedillo, the Mexican economy had performed well in the late 1990s, and there was a strong PRI base facing an opposition that had nominated two important presidential candidates. The divisiveness of the PRI primary had an initial adverse effect on Labastida, but it dissipated by the day of the general election (McCann 2004). Political mobilization, handouts, and home visits had only a modest effect (Cornelius 2004).

Instead, as already noted, the mass media had a significant impact. Those who watched Televisión Azteca news were more likely to vote for Fox than those who watched Televisa news (Lawson 2004b). The two televised debates between the candidates boosted audience impressions of Fox's leadership abilities, solidified his partisan base, and enabled him to lure some Labastida voters. The debates also reinforced support for Cárdenas from his own committed partisans (Lawson 2004c). Note that the debates had the expected partisan effect for Fox and Cárdenas: those leaning toward them became stronger supporters. The campaign in the mass media increased the likelihood that PAN and PRD sympathizers would vote, respectively, for Fox and Cárdenas on election day. In addition, negative political advertising worked for Fox in detaching some 
Labastida supporters, but Labastida's own negative advertising backfired on his campaign. The main effect on Labastida was that some of his voters stayed home, not that they switched to Fox (Moreno 2004).

Fox succeeded, thanks to his use of the mass media, in framing the election as being about change. All candidates, including Labastida, accepted this framing, hopeless as it was for a candidate whose party had governed Mexico for seven decades and whose incumbent president warranted a campaign based on continuity of good economic results, not change. A second Labastida/PRI strategic mistake was therefore to fail to embrace President Zedillo's record and high personal popularity. In the second half of the 1990s, the economy grew 5 to 6 percent per year, double the growth rate in the first half of the 1990s and nearly triple the growth rate during the 1980s.

Fox also persuaded a key fraction of the high political-interest attentive public that he was more likely than Cárdenas to beat the PRI. A vote for Fox would be "useful," the PAN campaign insisted, while voting for Cárdenas would waste the opportunity to oust the PRI. Magaloni and Poiré (2004a) have demonstrated that most voters behaved according to their partisanship and economic and candidate assessments, but that a small number of voters did behave strategically: they suppressed their ideological and policy preference for the candidate of the Left, Cárdenas, a hero of the democratic transition, and voted instead for Fox because he was more likely to beat the PRI. Strategic voting was thus modest but crucial. In effect, there were two simultaneous elections under way: one between opposition candidates and another between the opposition and the ruling party. Fox won both. The number of strategic voters in 2000 nearly equaled Fox's margin of victory over Labastida. 
Partisan defectors were a small fraction of all voters. The core of each major candidate's vote pool was the sum of his own partisans plus a share of the independent vote. But the effects of these patterns were quite different on the three main candidates. The campaigns solidified partisan support for Fox and Cárdenas, which is entirely consistent with the generalization that campaigns turn voters toward the expected outcome - they come home! Yet the strategic mistakes of the Labastida campaign induced some voters likely to choose Labastida to remain home; thus a lower PRI voter turnout, not so much PRI voter defection, hurt Labastida. The Fox campaign also lured some likely Cárdenas voters to vote strategically, suppressing their ideological and policy preferences on the Left to vote for the PRI dragon-slayer Fox.

The 2006 presidential election featured some of the same campaign processes, but this time leading the voters toward the expected outcome. At the start of the campaign season, López Obrador was ahead — a tribute to his personal skill. But the underlying factors favored a second PAN presidential victory. At the start of the campaign, voters had a much higher opinion of López Obrador than they did of his party, the PRD. The party was one of López Obrador's liabilities down to election day, when the presidential candidate far outperformed the PRD congressional candidates (see Table 22-1). Also the economy performed well heading into the 2006 election; unemployment had been falling steadily for nearly two years. And voters had a very high regard for the incumbent president, Vicente Fox, who was more popular than any of the three presidential candidates (Loaeza 2006).

How did Calderón win? That is, how did he employ his campaign to make the expected outcome more likely? First, he learned as the campaign unfolded. He won the 
PAN primary by emphasizing his personal honesty and his commitment to "values." Calderón, a Roman Catholic, retained his emphasis on values in the early stages of the general election campaign, including a socially conservative turn in February 2006 on issues such as abortion and contraception. His campaign failed to advance; he learned and changed his message. He embraced the Fox presidency and its record on the economy. Calderón thus recognized and built on his political assets: the popularity of an incumbent from his own party, the economy's recent good record, and the strong PAN partisan base - the opposite of the Labastida 2000 campaign strategy, which had shunned his president, his president's economic record, and promised change in the face of seventyone years of PRI rule. If Fox on behalf of the PAN had promised change in the 2000 election, Calderón on behalf of the same party promised continuity in the 2006 election. The Calderón campaign emphasized economic issues and launched its highly effective negative mass media campaign on López Obrador, accusing him of being a "danger to Mexico" (Moreno 2009a, 2009b; Valdivia and Beltrán 2009).

In the second stage of the 2006 presidential campaign, Calderón moved away from his own and his party's commitment to socially conservative positional issues on abortion and relations with the United States; President George W. Bush was dramatically unpopular with Mexican voters (McCann 2009). Instead Calderón emphasized valence issues, namely, salient problems for the voters on which he would claim superior competence. The Calderón campaign argument against López Obrador emphasized the latter's alleged dangerousness (Treviño Rangel 2009) and incompetence. Calderón primed the issue that electing López Obrador would lead to an economic crisis, just as Fox had primed change in 2000. Priming encourages voters to attach greater importance 
to a particular issue as they choose for whom to vote (Bartels 2006). Priming did not require persuading more voters to fear López Obrador's economic management. Rather it made those voters who were already concerned about this valence issue put more weight on it as a factor in their vote choice, and it may have increased their turnout on election day. Voters came to see Calderón as more competent to manage the economy. In October 2005 Calderón trailed López Obrador by 15 percentage points among independent voters with positive views of the economy; in July 2006 Calderón was ahead of López Obrador by 14 points among the same set of voters (Greene 2009). Priming worked for Calderón.

López Obrador had long followed a crisis management style that led him to stay quiet during controversies until the political furor died down. In the 2006 campaign, he mistakenly failed to respond to negative campaign advertising that portrayed him as a radical populist. In his most notable campaign gaffe, he failed to show up at the first of two televised debates scheduled during the presidential campaign. The PAN, the PRI, and the television stations left his chair empty and visible on the set (Bruhn 2009). When López Obrador began to respond, he primed his own economic issues, but that is not why voters had supported him in the first place. In the end, he relied disproportionately on PRD backers, but there were not enough of them. López Obrador might have emphasized what had made him popular in the first place: his political moderation. His issue positions were to the right of the PRD and very close to those of Mexico's median voter. He did not (Bruhn 2009; Bruhn and Greene 2009).

Issue ownership (change, the economy) and mass media effects helped to elect Fox in 2000 and Calderón in 2006. In 2000 this approach helped Fox to undermine Labastida's strengths at the start of the campaign; in 2006 it allowed Calderón to 
capitalize on the underlying strengths that any PAN candidate would have had going into the election: a bigger PAN than PRD partisan base, Fox's popularity, and an economy that had begun to grow. To win in 2006, López Obrador's campaign would have had to have been flawless, and it was not. To lose in 2000, Labastida had to make several errors, and he did.

In both elections, the principal effect of the campaign was to steer voters to the underlying factors that shape who they are and what they wish. Their experiences, preferences, networks of friends, and hopes for the future predispose them toward a political party. These sentiments and views are activated during campaigns. That is why parties and campaigns matter: the first shape the standing decisions of the electorate, and the second induce the electorate to remember those standing decisions and act accordingly. The ultimate challenges of campaigns are to identify the relatively small number of voters whose valence issue preferences may be primed to tilt their behavior and increase their turnout, or that similarly small number of supporters for an adversary who may be induced to stay home on election day, or that most esoteric set - present in 2000 but not in 2006 - who vote strategically, suppressing their policy preferences to accomplish political regime change.

In conclusion, since 1988 every Mexican presidential election has demonstrated that partisanship, evaluation of the incumbent president's performance, and economic assessments shaped the views of voters. Since 2000 assessments of candidates and the role of the mass media and campaign strategies have come to matter a great deal. Campaigns in Mexico, as in other countries, activate the public's preferences and remind cross-pressured citizens about their priorities. By the current decade, old-style clientelist 
practices in elections had come to matter less, and by 2006 strategic voting had also become less important. In terms of campaign strategies, negative advertising and the priming of valence issues caught the attention of candidates for their effectiveness. Mexican democrats had become free to be uplifting — or nasty.

\section{The End of the 2006 Campaign}

On July 3, 2006, the day after the presidential election, López Obrador asserted on national television that three million votes had disappeared. He challenged the election result; he called large, frequent public meetings in protest. On July 30, in front of hundreds of thousands of supporters, he called for civil disobedience to compel the authorities to recognize his electoral victory. Tents and barricades went up in downtown Mexico City, paralyzing the movement of people for forty-seven days. This strategy did not work. Fox's popularity soared during these postelection months, and public support for López Obrador plummeted. Yet on September 16, at yet another massive public meeting, López Obrador claimed to be the "legitimate president," and on November 20 he went through a formal ceremony of installation as Mexico's president. On December 1 Felipe Calderón was inaugurated as president of Mexico at a tumultuous meeting of Congress. The shouting and shoving came to an end once the national anthem was played (Loaeza 2007). In the subsequent weeks, months, and years, López Obrador's star waned. The PRD share of the vote for candidates for the Chamber of Deputies plunged from 29.7 percent in 2006 to 12.9 percent in 2009 (calculated from Instituto Federal Electoral 2010). President Felipe Calderón was the president indeed; Mexicans came to accept him 
in this role even as they and academics (Crespo 2009; Aparicio 2009) continued to debate the presidential election result.

\section{References}

Alesina, A., and H. Rosenthal. 1995. Partisan Politics, Divided Government, and the Economy. Cambridge: Cambridge University Press.

Aparicio, J. 2009. “Análisis estadístico de la elección presidencial de 2006: Fraude o errores aleatorios?" Politica y Gobierno, special issue, 2:225-43.

Aziz Nassif, A., and E. Isunza Vera. 2007. "La crisis del modelo electoral mexicano: Financiamiento, medios, instituciones y política social.” Foro Internacional 47:74084.

Bartels, L. 2006. “Priming and Persuasion in Presidential Campaigns.” In Capturing Campaign Effects, ed. H. Brady and R. Johnston. Ann Arbor: University of Michigan Press.

Bruhn, K. 1997. Taking on Goliath: The Emergence of a New Left Party and the Struggle for Democracy in Mexico. University Park: Pennsylvania State University Press.

_. 2004. "The Making of the Mexican President, 2000: Parties, Candidates, and Campaign Strategy." In Mexico's Pivotal Democratic Election: Candidates, Voters, and the Presidential Campaign of 2000, ed. J. Domínguez and C. Lawson. Stanford, Calif.: Stanford University Press.

—_. 2009. "López Obrador, Calderón, and the 2006 Presidential Campaign.” In Consolidating Mexico's Democracy: The 2006 Presidential Campaign in 
Comparative Perspective, ed. J. Domínguez, C. Lawson, and A. Moreno. Baltimore: Johns Hopkins University Press.

Bruhn, L., and K. Greene. 2009. "The Absence of Common Ground between Candidates and Voters." In Consolidating Mexico's Democracy: The 2006 Presidential Campaign in Comparative Perspective, ed. J. Domínguez and C. Lawson. Baltimore: Johns Hopkins University Press.

Camp, R. 2007. Politics in Mexico: The Democratic Consolidation. 5th ed. New York: Oxford University Press.

—. 2008. "Exercising Political Influence: Religion, Democracy, and the Mexican 2006 Presidential Race.” Journal of Church and State 50:49-72.

Campbell, A., P. Converse, W. Miller, and D. Stokes. 1960. The American Voter. New York: Wiley.

Cornelius, W. 2004. "Mobilized Voting in the 2000 Elections: The Changing Efficacy of Vote Buying and Coercion in Mexican Politics." In Mexico's Pivotal Democratic Election: Candidates, Voters, and the Presidential Campaign of 2000, ed. J.

Domínguez and C. Lawson. Stanford, Calif.: Stanford University Press.

Crespo, J. 2009. “El proceso de escrutinio y cómputo: Omisiones de las autoridades electorales." Politica y Gobierno, special issue, 2:201-24.

Díaz-Cayeros, A. 2006. Federalism, Fiscal Authority, and Centralization in Latin America. New York: Cambridge University Press.

Domínguez, J., and R. Fernández de Castro. 2009. The United States and Mexico: Between Partnership and Conflict. 2nd ed. New York: Routledge. 
Domínguez, J., and C. Lawson, eds. 2004. Mexico's Pivotal Democratic Election: Candidates, Voters, and the Presidential Campaign of 2000. Stanford, Calif.: Stanford University Press.

Domínguez, J., C. Lawson, and A. Moreno, eds. 2009. Consolidating Mexico's Democracy: The 2006 Presidential Campaign in Comparative Perspective. Baltimore: Johns Hopkins University Press.

Domínguez, J., and J. McCann. 1996. Democratizing Mexico: Public Opinion and Electoral Choices. Baltimore: Johns Hopkins University Press.

Eisenstadt, T. 2004. Courting Democracy in Mexico: Party Strategies and Electoral Institutions. New York: Cambridge University Press.

Flores-Macías, F. 2009. "Electoral Volatility in 2006.” In Consolidating Mexico's Democracy: The 2006 Presidential Campaign in Comparative Perspective, ed. J. Domínguez, C. Lawson, and A. Moreno. Baltimore: Johns Hopkins University Press. Freidenberg, F., and L. González Tule. 2009. “Estrategias partidistas, preferencias ciudadanas y anuncios televisivos: Un análisis de la campaña electoral mexicana de 2006." Política y Gobierno 16:269-320.

Garrido, L. J. 1987. “Un partido sin militantes.” In La vida política en la crisis, ed. S. Loaeza and R. Segovia. Mexico City: El Colegio de México.

Gelman, A., and G. King. 1993. "Why Are American Presidential Election Polls So Variable When Voters Are So Predictable?" British Journal of Political Science 26:409-51.

Gómez Tagle, S. 1989. "La dificultad de perder: El partido oficial en la coyuntura de 1988." Revista mexicana de sociología 51:240-42. 
—. 2004. "Public Institutions and Electoral Transparency in Mexico." In Dilemmas of Political Change in Mexico, ed. K. Middlebrook. London: Institute of Latin American Studies, University of London.

Greene, K. 2007. Why Dominant Parties Lose: Mexico's Democratization in Comparative Perspective. New York: Cambridge University Press.

—. 2009. "Images and Issues in Mexico’s 2006 Presidential Election.” In Consolidating Mexico's Democracy: The 2006 Presidential Campaign in Comparative Perspective, ed. J. Domínguez, C. Lawson, and A. Moreno. Baltimore: Johns Hopkins University Press.

Guardado Rodríguez, J. 2009. "La identidad partidista en México: Las dimensiones políticas de la competencia en las elecciones presidencias de 2000 y 2006.” Política y Gobierno, special issue, 1:137-75.

Haber, S., H. Klein, N. Maurer, and K. Middlebrook. 2008. Mexico since 1980. New York: Cambridge University Press.

Hernández Rodríguez, R. 2009. “Una competencia sin reglas: La candidatura presidencial de Roberto Madrazo." Política y Gobierno, special issue, 2:15-49. Holbrooke, T. 1996. Do Campaigns Matter? Thousand Oaks, Calif.: Sage. Instituto Federal Electoral. 2010. www.ife.org.mx. Langston, J. 2009. “The PRI's 2000 Presidential Campaign.” In Consolidating Mexico's Democracy: The 2006 Presidential Campaign in Comparative Perspective, ed. J. Domínguez, C. Lawson, and A. Moreno. Baltimore: Johns Hopkins University Press. 
Lau, R., L. Sigelman, C. Heldman, and P. Babbitt. 1999. “The Effects of Negative Political Advertisements: A Meta-analytic Assessment.” American Political Science Review 93:877-89.

Lawson, C. 2002. Building the Fourth Estate: Democratization and the Rise of a Free Press in Mexico. Berkeley: University of California Press.

-2004a. Introduction to Mexico's Pivotal Democratic Election: Candidates, Voters, and the Presidential Campaign of 2000, ed. J. Domínguez and C. Lawson. Stanford, Calif.: Stanford University Press.

—. 2004b. "Television Coverage, Vote Choice, and the 2000 Campaign." In Mexico's Pivotal Democratic Election: Candidates, Voters, and the Presidential Campaign of 2000, ed. J. Domínguez and C. Lawson. Stanford, Calif.: Stanford University Press.

—. 2004c. “Mexico’s Great Debates: The Televised Candidate Encounters of 2000 and Their Electoral Consequences.” In Mexico's Pivotal Democratic Election:

Candidates, Voters, and the Presidential Campaign of 2000, ed. J. Domínguez and C. Lawson. Stanford, Calif.: Stanford University Press.

Lewis-Beck, M. 1988. Economics and Elections: The Major Western Democracies. Ann Arbor: University of Michigan Press.

Loaeza, S. 1999. El Partido Acción Nacional: La larga marcha, 1939-1994. Oposición leal y partido de protesta. Mexico City: Fondo de Cultura Económica. —. 2003. “Acción Nacional en la antesala del poder: 1994-2000.” Foro Internacional 43:71-102. 
—. 2006. "Vicente Fox's Presidential Style and the New Mexican Presidency." Mexican Studies 22:1-32.

_ 2007. "La desilusión mexicana: Populismo y democracia en México en el 2006." Foro Internacional 47:816-38.

Magaloni, B. 1999. "Is the PRI Fading? Economic Performance, Electoral Accountability, and Voting Behavior in the 1994 and 1997 Elections." In Toward Mexico's Democratization: Parties, Campaigns, Elections, and Public Opinion, ed. J. Domínguez and A. Poiré. New York: Routledge.

—. 2006. Voting for Autocracy: Hegemonic Party Survival and Its Demise in Mexico. New York: Cambridge University Press.

Magaloni, B., and Alejandro Poiré. 2004a. "Strategic Coordination in the 2000 Mexican Presidential Race.” In Mexico's Pivotal Democratic Election: Candidates, Voters, and the Presidential Campaign of 2000, ed. J. Domínguez and C. Lawson. Stanford, Calif.: Stanford University Press.

Magaloni, B., and Alejandro Poiré. 2004b. "The Issues, the Vote, and the Mandate for Change." In Mexico's Pivotal Democratic Election: Candidates, Voters, and the Presidential Campaign of 2000, ed. J. Domínguez and C. Lawson. Stanford, Calif.: Stanford University Press.

McCann, J. 2004. “Primary Priming." In Mexico's Pivotal Democratic Election: Candidates, Voters, and the Presidential Campaign of 2000, ed. J. Domínguez and C. Lawson. Stanford, Calif.: Stanford University Press. 
_.2009. "Ideology in the 2006 Campaign." In Consolidating Mexico's

Democracy: The 2006 Presidential Campaign in Comparative Perspective, ed. J.

Domínguez, C. Lawson, and A. Moreno. Baltimore: Johns Hopkins University Press.

McCann, J., and J. Domínguez. 1998. "Mexicans React to Electoral Fraud and Political Corruption: An Assessment of Public Opinion and Voting Behavior.” Electoral Studies 17:493-503.

Mizrahi, Y. 2003. From Martyrdom to Power: The Partido Acción Nacional in Mexico. Notre Dame, Ind.: University of Notre Dame Press.

Modoux, M. 2006. “Geografía de la gobernanza ¿La alternancia partidaria como factor de consolidación del poder de los gobernadores en el escenario nacional mexicano?" Foro Internacional 46:513-32.

Moreno, A. 2003. El votante mexicano: Democracia, actitudes políticas, y conducta electoral. Mexico City: Fondo de Cultura Económica.

—. 2004. "The Effects of Negative Campaigns on Mexican Voters." In Mexico's Pivotal Democratic Election: Candidates, Voters, and the Presidential Campaign of 2000, ed. J. Domínguez and C. Lawson. Stanford, Calif.: Stanford University Press. _ 2009a. "The Activation of Economic Voting in the 2006 Campaign." In Consolidating Mexico's Democracy: The 2006 Presidential Campaign in Comparative Perspective, ed. J. Domínguez, C. Lawson, and A. Moreno. Baltimore: Johns Hopkins University Press.

_.2009b. La decisión electoral: Votantes, partidos, y democracia en México. Mexico City: Porrúa. 
Nie, N., S. Verba, and J. Petrocik. 1976. The Changing American Voter. Cambridge, Mass.: Harvard University Press.

Norris, P, J. Curtice, D. Sanders, M. Scammell, and H. Semetko. 1999. On Message: Communicating the Campaign. London: Sage.

Ortega, R., and M. F. Somuano. 2003. "La identificación partidista de los mexicanos y el cambio electoral, 1994-2000.” Foro Internacional 43:10-38.

Peschard, J. 2006. "Control over Party and Campaign Finance in Mexico.” Mexican Studies 22:83-105.

Prud'homme, J.-F. 2003. “El Partido de la Revolución Democrática: Las ambivalencias de su proceso de institucionalización.” Foro Internacional 43:103-40.

Romero, V. 2009. "La herencia del presidente: Impacto de la aprobación presidencial en el voto." Política y Gobierno 16:3-35.

Salinas de Gortari, C. 2000. México: Un paso difícil a la modernidad. Barcelona: Plaza \& Janés.

Shickler, E., and D. Green. 1997. "The Stability of Party Identification in Western Democracies: Results from Eight Panel Surveys.” Comparative Political Studies $30: 450-83$.

Shirk, D. 2009. “Choosing Mexico’s 2006 Presidential Candidates.” In Consolidating Mexico's Democracy: The 2006 Presidential Campaign in Comparative Perspective, ed. J. Domínguez, C. Lawson, and A. Moreno. Baltimore: Johns Hopkins University Press.

Trelles, A., and H. Zagal. 2004. AMLO: Historia política y personal del candidato a la presidencia por el PRD. Mexico City: Debolsillo. 
Trelles, A., and H. Zagal. 2006. Anatomía del PRI: Claves para entender a Roberto Madrazo. Mexico City: Plaza Janés.

Treviño Rangel, J. 2009. "Pánico moral en las campañas electorales de 2006: La elaboración del 'peligro para México.'” Foro Internacional 49:638-89.

Valdivia, M., and U. Beltrán. 2009. “Dilemas de estrategia: Tierra o aire?” Política y Gobierno, special issue, 1:177-98.

Virriel López, C. 2000. "El problema de la credibilidad de los spots políticos." Revista mexicana de ciencias políticas y sociales 44:175-90.

Zaller, J. 2002. The Nature and Origins of Mass Opinion. Cambridge: Cambridge University Press.

Table 22-1. Percentage of Votes Cast for President and Federal Deputy, 2000 and 2006

\begin{tabular}{|l|l|l|l|l|}
\hline Party/coalition & President 2000 & Deputy 2000 & President 2006 & Deputy 2006 \\
\hline PAN & 43.4 & 39.1 & 36.7 & 34.2 \\
\hline PRI & 36.9 & 37.8 & 22.7 & 28.9 \\
\hline PRD & 17.0 & 19.1 & 36.1 & 29.7 \\
\hline Other parties & 2.7 & 3.9 & 4.5 & 7.1 \\
\hline Valid votes cast & $36,813,461$ & $36,302,508$ & $40,886,718$ & $40,161,533$ \\
\hline
\end{tabular}

Source: Instituto Federal Electoral 2010.

Note: In 2000, PAN = Alianza por el Cambio (in coalition with the Partido Verde

Ecologista Mexicano, PVEM); PRD = Alianza por México (in coalition with the Partido 
del Trabajo, PT). In 2006, PRI = Alianza por México (in coalition with the PVEM); PRD

$=$ Por el Bien de Todos (in coalition with Convergencia Democrática, CD, and the PT).

\footnotetext{
${ }^{2}$ I was a member of the Gallup team that received the letter from the Ministry.
} 